\title{
Synchronization of the NGRIP, GRIP, and GISP2 ice cores across MIS 2 and palaeoclimatic implications
}

\author{
S. O. Rasmussen ${ }^{1}$, I. K. Seierstad, K. K. Andersen, M. Bigler, \\ D. Dahl-Jensen, S. J. Johnsen \\ Ice and Climate Research, Niels Bohr Institute, University of Copenhagen, \\ Juliane Maries Vej 30, DK-2100 Copenhagen, Denmark.
}

Accepted for publication in Quaternary Science Reviews, $200 \%$.

\begin{abstract}
We here present a synchronization of the NGRIP, GRIP, and GISP2 ice cores based mainly on volcanic events over the period $14.9-32.45 \mathrm{ka}$ b2k (before A.D. 2000), corresponding to Marine Isotope Stage 2 (MIS 2) and the end of MIS 3. The matching provides a means to apply the recent NGRIP-based Greenland Ice Core Chronology 2005 (GICC05) time scale to the GRIP and GISP2 ice cores, thereby making it possible to compare the synchronized palaeoclimate profiles of the cores in detail and to identify relative accumulation differences between the cores. Based on the matching, a period of anomalous high accumulation rates in the GISP2 ice core is detected within the period $16.5-18.3 \mathrm{ka} \mathrm{b} 2 \mathrm{k}$. The $\delta^{18} \mathrm{O}$ and $\left[\mathrm{Ca}^{2+}\right]$ profiles of the three cores are presented on the common GICC05 time scale and generally show excellent agreement across the stadial-interstadial transitions and across the two characteristic dust events in Greenland Stadial 3. However, large differences between the $\delta^{18} \mathrm{O}$ and $\left[\mathrm{Ca}^{2+}\right]$ profiles of the three cores are seen in the same period as the $7-9 \%$ increase in the GISP2 accumulation rate. We conclude that changes of the atmospheric circulation are likely to have occurred in this period, altering the spatial gradients in Greenland and resulting in larger variations between the records.
\end{abstract}

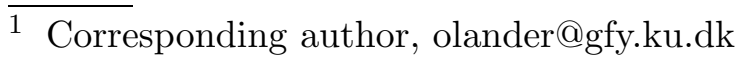




\section{Introduction}

Ice core data provide climate records of excellent resolution across the late glacial period, but detailed comparisons between different ice cores have been hampered by the lack of a common time scale. Comparisons of glacial ice core records have in general been made by assuming that the Greenland stadial-interstadial transitions as recorded by the $\delta^{18} \mathrm{O}$ signals are synchronous, but this approach has a limited accuracy because the $\delta^{18} \mathrm{O}$ transitions do not always look alike in different cores, and the assumption of simultaneous transitions means that possible leads and lags cannot be assessed (Bender et al., 1994). Synchronization of ice cores using gas records is also possible, but the determination of the ice age-gas age offset is not trivial, and smoothing takes place when the gas is enclosed in the bubbles of the ice (Blunier and Schwander, 2000). This makes the method less attractive for highresolution synchronization of Greenland ice cores, while it has proven very successful for synchronizing Greenland and Antarctic records (Blunier and Brook, 2001). The situation is especially difficult during the millennia-long periods without abrupt climatic transitions in the late part of the glacial. In the very latest part of the glacial the $\delta^{18} \mathrm{O}$ profiles of the Greenland ice cores are significantly different (e.g. NGRIP members, 2004; Johnsen et al., 2001; Svensson et al., accepted), making synchronization even more difficult.

As discussed by Southon (2004), the time scales of the Greenland Ice Sheet Project 2 (GISP2) and Greenland Ice Core Project (GRIP) ice cores differ significantly in the glacial period, which can be partially explained by the very different dating approaches applied. The glacial section of the GISP2 time scale was made by counting annual layers, identified mainly from visual inspection of the core stratigraphy (Alley et al., 1997; Meese et al., 1997), while the glacial part of the GRIP ice core was dated using an ice flow model incorporating an empirical $\delta^{18} \mathrm{O}$-accumulation relationship and two independently dated fix-points (Dansgaard et al., 1993; Johnsen et al., 1995), leading eventually to the improved ss09sea time scale (Johnsen et al., 2001). This time scale was transferred to NGRIP by using climatic transitions as observed in the $\delta^{18} \mathrm{O}$ profiles and a number of prominent volcanoes as match points (NGRIP members, 2004).

Recently the DYE-3, GRIP, and NGRIP ice cores have been dated in parallel by annual layer counting in the Holocene as part of the Greenland Ice Core Chronology 2005 (GICC05) effort (Vinther et al., 2006; Rasmussen et al., 2006, accepted). Data from all three cores have been used to construct the common GICC05 time scale, and the cores are synchronized with a maximum offset of a few years. Below the Preboreal - Younger Dryas transition the GICC05 time scale is based on NGRIP data alone and currently reaches back to about $42 \mathrm{ka}$ b2k (before the year A.D. 2000) (Andersen et al., accepted). The GICC05 agrees with the GISP2 time scale 
at the onset of Greenland interstadial ${ }^{2} 1$ (GI-1) and the agreement is fairly good at the onsets of many of the interstadials. However, relative differences between the two time scales of about $10 \%$ and more than $30 \%$ are observed in the BøllingAllerød period and in some sections of the glacial, respectively (Rasmussen et al., 2006; Svensson et al., accepted).

Here we present a synchronization of the NGRIP, GRIP, and GISP2 ice cores from the onset of GI-1 to GI-5, 14.9 - $32.45 \mathrm{ka} \mathrm{b2k}$, corresponding to Marine Isotope Stage 2 (MIS 2) and the end of MIS 3. The synchronization is based on identification of volcanic events that have been recorded in at least two of the three cores, similar to the method used to transfer the GICC05 time scale from NGRIP depths to GRIP depths across the last termination (11.7 - $14.8 \mathrm{ka} \mathrm{b2k)}$ (Rasmussen et al., 2006). In the present work we also match the records using peaks in the $\left[\mathrm{NH}_{4}^{+}\right]$profiles, probably originating from biomass burning (Fuhrer et al., 1996; Taylor et al., 1996). Volcanic and biomass burning events have been used as time markers because they represent distinct peaks that stand out from the climate-dependent background levels. Furthermore they are recorded almost simultaneously across the area where they are detected, while e.g. $\delta^{18} \mathrm{O}$ cannot be assumed to change simultaneously across Greenland.

The obtained match points have been used to apply the GICC05 time scale to the GRIP and GISP2 ice cores, and the synchronization makes it possible to investigate regional differences between the three records and to determine the relative timing of climatic changes as recorded in the three ice cores.

\section{Data}

Explosive volcanic eruptions emit large amounts of tephra (e.g. ash) and gases (e.g. $\mathrm{SO}_{2}$ ) into the atmosphere. Oxidation and gas-to-particle conversion transforms $\mathrm{SO}_{2}$ to sulfuric acid $\left(\mathrm{H}_{2} \mathrm{SO}_{4}\right)$. Volcanic events are therefore recorded in ice cores mainly as acidic peaks (Clausen et al., 1997; Hammer et al., 1980, 1997) and sulfate peaks (Zielinski et al., 1994; Zielinski, 2000; Bigler et al., 2002), although tephra particles also may be found (Palais et al., 1991; Grönvold et al., 1995; Mortensen et al., 2005). Electrical Conductivity Measurements (ECM), Dielectric Profiling (DEP), and $\left[\mathrm{SO}_{4}^{2-}\right]$ measurements are the main data used for detection of volcanic events. The ECM profile is a measure of the $\left[\mathrm{H}^{+}\right]$of the ice and is obtained by moving a set of electrodes with a large voltage difference along a cleaned section of the core (Hammer, 1980). Also the dielectric properties of the core are affected by the acidity (Moore et al., 1989), but both volcanic ECM and DEP peaks can be weakened or even obliterated in sections with high dust level due to the increased alkalinity. The

2 The Greenland Stadials (GS) and Greenland Interstadials (GI) are numbered according to the convention of Björck et al. (1998) and Walker et al. (1999). 
large peaks in the $\left[\mathrm{SO}_{4}^{2-}\right]$ profile must thus be considered the most reliable indicator of past volcanic activity in ice cores.

The data series used in this work are listed in Table 1 together with information on the resolution and data references. Measurements of $\left[\mathrm{SO}_{4}^{2-}\right],\left[\mathrm{NH}_{4}^{+}\right]$, and $\left[\mathrm{Ca}^{2+}\right]$ have been performed on melted samples of ice core, either as discrete samples used for ion chromatography (IC) or as Continuous Flow Analysis (CFA) measurements (Röthlisberger et al., 2000). [ $\left.\mathrm{SO}_{4}^{2-}\right]$ has only been measured within shorter sections of the GRIP core, but the other data profiles cover the entire section investigated. It should be noted that the depth resolution values given in Table 1 for the CFA data are the sampling resolution values, which are somewhat smaller than the shortest events that can be detected in the measured profiles. For the CFA data, the depth assignment has an uncertainty in the $1-2 \mathrm{~cm}$ range, while the GRIP and NGRIP ECM data can be offset from true depth by up to $5 \mathrm{~cm}$ due to less accurate depth control in the measurement setup.

\section{Method}

The use of volcanic deposits is the most direct and well-understood method for highresolution synchronization of ice records (e.g., Langway et al., 1988; Wolff et al., 1999; Udisti et al., 2004; Bay et al., 2006). A study of recent volcanic deposits in Antarctica shows that the sulphate peaks typically start $1-3$ years after the eruption and last $1-3$ years (Palmer et al., 2001). In the construction of the GICC05 time scale, the DYE-3, GRIP, and NGRIP cores have been dated in parallel using annual cycles in $\delta^{18} \mathrm{O}$ data back to $1814 \mathrm{~b} 2 \mathrm{k}$, and based on the experiences obtained in this interval, the maximum difference in arrival times and peak maximum location between two Greenland sites is estimated to one year. When volcanic fallout from a certain eruption is found in two or more cores, the layer can therefore be regarded as an almost simultaneous event. However, volcanic fallout is not distributed evenly, which is clearly seen by the fact that many volcanic layers are found in one of the two Central Greenland GRIP and GISP2 cores, located about $30 \mathrm{~km}$ apart, and not in the other.

The NGRIP, GRIP, and GISP2 cores have been matched by synchronizing volcanic signals in the section corresponding to the 14.9 - $32.45 \mathrm{kyr}$ b2k time interval. A graphical Matlab application ("Matchmaker") was designed to facilitate the matching procedure by allowing the user to scale and display the available data series for each core and align common features in an efficient way.

As a first step the three ice core records were matched on a coarse scale using the stadial-interstadial transitions observed in the climate profiles of e.g. $\delta^{18} \mathrm{O}$ and $\left[\mathrm{Ca}^{2+}\right]$. These first match points based on climatic events served only to align the curves before looking for potential synchronous volcanic events, appearing as peaks 
in the profiles of ECM, DEP, $\left[\mathrm{SO}_{4}^{2-}\right]$ and at times $\left[\mathrm{Ca}^{2+}\right]$, and were not used for the final synchronization. Characteristic peaks observed in the data profiles were chosen manually to define match points (time-marker horizons) between the different cores, representing synchronous events. The selected match points were mainly volcanic events, but the synchronization was sometimes supported by features of non-volcanic origin, such as characteristic patterns of $\left[\mathrm{NH}_{4}^{+}\right]$peaks appearing with similar spacing in two or three cores. These patterns of typically $3-5$ adjacent peaks support that the correct volcanic events have been matched, but they have not been used for the synchronization. However, a number of very strong individual $\left[\mathrm{NH}_{4}^{+}\right]$peaks have been chosen as match points.

To validate that the resulting match points do represent synchronous volcanic depositions, the depths of the match points $d_{1}, \ldots, d_{N}$ and $D_{1}, \ldots, D_{N}$ in two cores are plotted against each other. The slope of this curve is the ratio of the annual layer thicknesses in the two cores. This ratio depends on the ratio of the accumulation rates and the flow-related thinning rates at two drill sites, and must be expected to change only slowly except across stadial-interstadial transitions. If an event is matched incorrectly, this will be reflected in the slope of the curve, but if viewed over long sections, only very large discrepancies will be readily apparent due to the large range of values. If for example the match points span $200-300 \mathrm{~m}$ of ice core as is the case in this work, offsets of a few tens of centimeters will only be visible as minor wiggles on the curve. By plotting $d_{i}-D_{i}$ versus $D_{i}$ a more sensitive quality check can be performed. The depth difference $d_{i}-D_{i}$ will vary smoothly under stable climatic conditions, and mismatched events will also here show up in the curve as kinks or sections with large curvature. However, due to the much smaller range of values taken on by $d_{i}-D_{i}$, the discrepancies will be much more easily visible when plotted. An even more sensitive approach is to calculate the ratio $r_{i}$ of the distances between adjacent match points in one core relative to the other: $r_{i}=\left(D_{i+1}-D_{i}\right) /\left(d_{i+1}-d_{i}\right)$ for $i=1, \ldots, N-1$. Assuming that the accumulation rate at each site is rather constant within a climate period and that no abrupt changes in the flow pattern with depth occur, this ratio should remain constant or at least only change slowly. This will of course only be the case as long as the distance between adjacent match points is large enough to prevent that the results are seriously affected by problems with depth control, depositional noise, and shortrange accumulation rate variability, which are important factors when the match point spacing is less than a few decades (Fisher et al., 1985). The latter two of the three validation methods have been used simultaneously while performing the synchronization in order to continuously evaluate the consistency of the match points. The results are here presented as plots of depth difference $d_{i}-D_{i}$ versus depth $D_{i}$. In these plots, the slope of the curves corresponds to the relative annual layer thickness deviation between the two cores, where a slope of e.g. 0.03 corresponds to the annual layers core in core $d$ being $3 \%$ thicker than those of core $D$.

Typical volcanic peaks span a depth interval from a few millimeters to about 15 $\mathrm{cm}$ in the cores, and different data series from the same core may peak at slightly different depths across this interval. These differences are likely to be caused by 

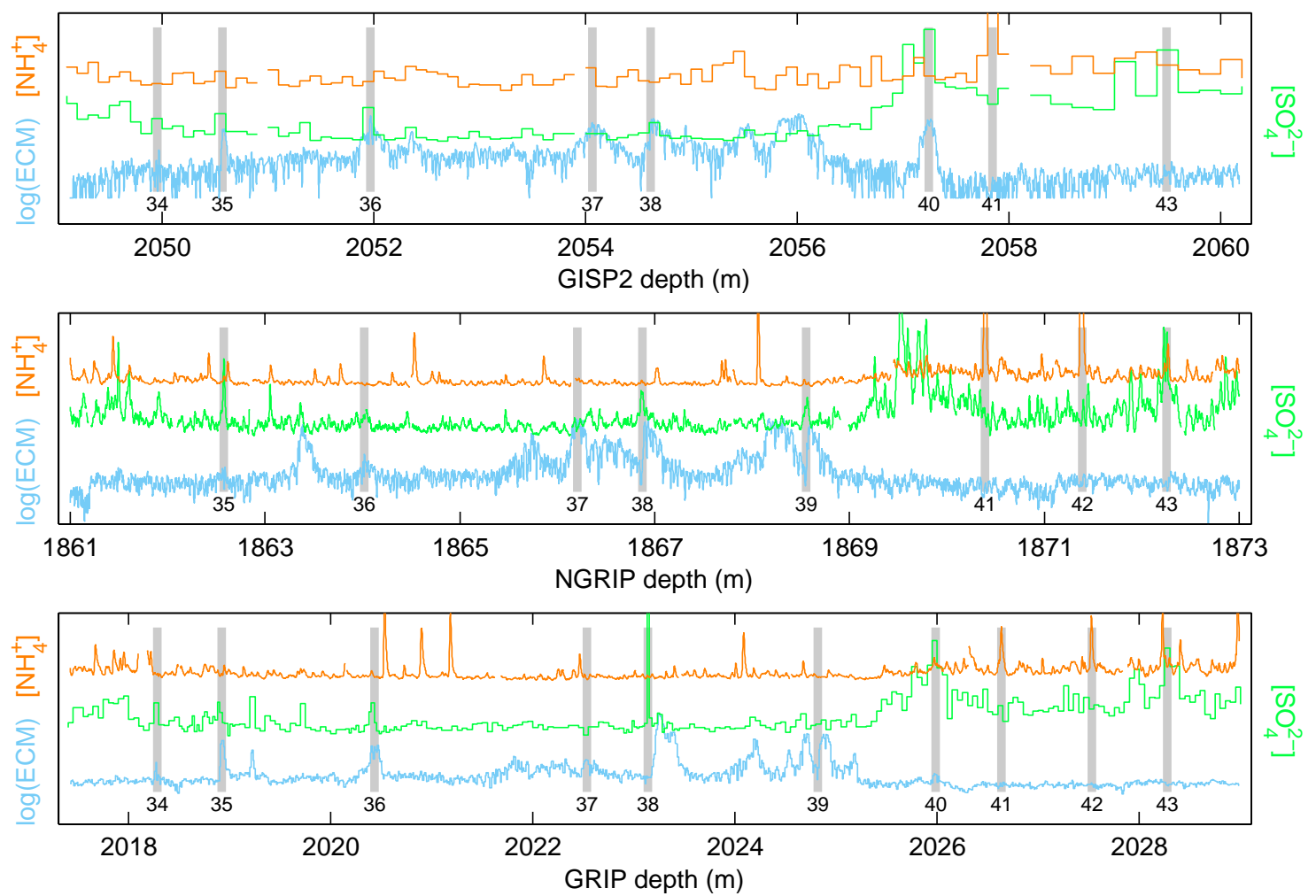

Fig. 1. Synchronized section of the three cores. The ECM, $\left[\mathrm{SO}_{4}^{2-}\right]$, and $\left[\mathrm{NH}_{4}^{+}\right]$data series are shown together with the match points. The numbers refer to the match point numbers in Table 2. The ECM peaks appear less well-defined because of the logarithmic axis. Match point 34 has only been found in the GRIP and GISP2 records, and match point 40 in NGRIP / 39 in GISP2 have not been set because their positions within the wide $\left[\mathrm{SO}_{4}^{2-}\right] /$ ECM peaks are uncertain. Number 42 cannot be set in GISP2 because it is based on $\left[\mathrm{NH}_{4}^{+}\right]$data, which are not available for the GISP2 core in sufficient resolution.

a combination of differences in transport paths and accumulation conditions, and artificial offsets due to problems with precise co-registration of the signals in different data series as mentioned in section 2 . The strategy applied here was to examine each volcanic event in detail and choose the most well-defined feature (e.g. the sharpest peak or the steepest flank) from the data series with highest possible resolution, at the same time checking that there is agreement between all other available data series. The precision of the synchronization is in general estimated to $10 \mathrm{~cm}$ or better. In some cases the peak shapes are wider or more offset between the cores, leading to less certain synchronization. Also the match points that have been based on GISP2 $\left[\mathrm{SO}_{4}^{2-}\right]$ and $\left[\mathrm{NH}_{4}^{+}\right]$data are less certain as the data resolution is $20 \mathrm{~cm}$.

The matching was performed both by having data from all three cores present at a time and also by matching the cores in pairs, i.e. GRIP-NGRIP, GRIP-GISP2 and GISP2-NGRIP. Three investigators performed the matching independently in order to validate the synchronization and check the reproducibility of the chosen match points. Match points identified by all investigators were accepted, and sections with discrepancies were revisited. In the case of discrepancies smaller than or about 10 
$\mathrm{cm}$, agreement was obtained by adjusting the exact positioning within the same volcanic event. Sections with larger discrepancies were re-matched independently by at least two investigators, and if the discrepancies remained, no match points were accepted in that section.

A synchronized section from the end of GI-3 is shown in Fig. 1 to illustrate how patterns of peaks can be recognized between cores and used for matching. It is also exemplified how some match points can only be used to synchronize two of the three cores because of ambiguous peak shapes and limited data resolution. It should be noted that the reliability of the individual match points cannot be adequately evaluated when showing 12 meters of data on a single plot because of the large dynamical range of the data values. The advantage of the Matchmaker application is indeed the opportunity to efficiently switch between detailed views of a certain peak and longer sequences of match points.

\section{Results}

Table 2 lists the match points between the NGRIP, GRIP, and GISP2 cores. 66 match points have been chosen within the 14.9 - $32.45 \mathrm{ka}$ b2k section, corresponding to an average spacing of about $250 \mathrm{yrs}$. The match points are unevenly distributed across the section, with spacing ranging from approximately 10 yrs (distance about $0.3 \mathrm{~m}$ ) to 2 kyrs (distance more than $40 \mathrm{~m}$ ). The most dense distribution of distinct volcanic match points is observed from GI-3 and below (match points $34-66$ ), and during the termination of GS-2 (match points $1-9$ ). In the intermediate part, the number of distinct volcanic peaks is smaller and the distance between adjacent match points is thus greater. As described above, only match points that all investigators independently agreed upon have been included in the synchronization, apart from a single exception. In the depth interval bounded by match points 24 and 28 the matching is ambiguous. We believe that match points $25-27$ represent by far the most likely synchronization, but acknowledge that other reasonable alignments of the cores are possible. In the middle of this section the matching may be an estimated 1 meter (or about 50 years) offset, although we find deviations of this magnitude to be unlikely.

Some match points are only found in two cores. This is especially the case for match points based on $\left[\mathrm{NH}_{4}^{+}\right]$peaks, because the $20 \mathrm{~cm}$ resolution of the GISP2 $\left[\mathrm{NH}_{4}^{+}\right]$data sometimes makes it difficult to make certain matches. This is both due to the fact that medium-size $\left[\mathrm{NH}_{4}^{+}\right]$peaks that are only a few centimeters wide in the continuous GRIP and NGRIP records disappear when averaging over $20 \mathrm{~cm}$ sections, but also that matching of characteristic patterns of peaks is only possible in high-resolution data. Most of the match points that are only found in the NGRIP and GISP2 cores have not been set in the GRIP core due to the absence of $\left[\mathrm{SO}_{4}^{2-}\right]$ data, which sometimes are needed to confidently identify a certain volcanic event. 
a)

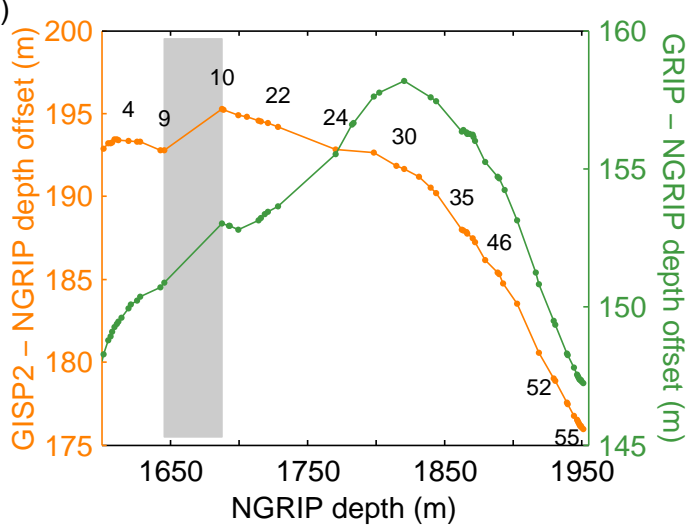

b)

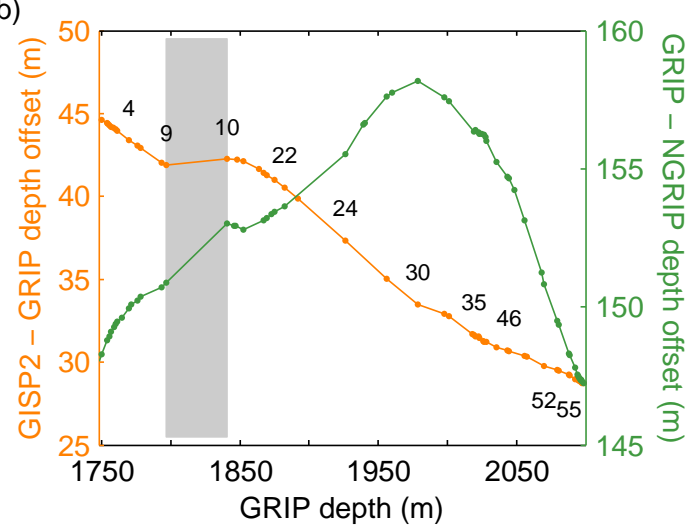

Fig. 2. Depth differences between the match points in the three cores plotted versus NGRIP depth (a) and GRIP depth (b). The numbers refer to the match point numbers in Table 2. The grey shaded area marks the interval between match points 9 and 10 (corresponding to 16.5 - $18.3 \mathrm{ka} \mathrm{b2k}$ ) where the GISP2-NGRIP and GISP2-GRIP depth difference curves (orange curves) have an unusual shape.

A somewhat surprising observation, given that the geographical distance between GRIP and GISP2 $(28 \mathrm{~km})$ is an order of magnitude smaller than the distance from GRIP/GISP2 to NGRIP (more than $300 \mathrm{~km}$ ), is that the general similarity of the GRIP and GISP2 records is not significantly different from the similarity of the NGRIP and GRIP/GISP2 records.

Fig. 2 shows the depth differences plotted versus NGRIP and GRIP depths, respectively. In general the curves are smooth and have small curvature. Initially disregarding the grey shaded area between match points 9 and 10, the GISP2-GRIP depth difference (Fig. 2b, orange curve) is positive and monotonously decreasing with depth, because the slightly higher accumulation rates at GISP2 (Alley et al., 1993; Meese et al., 1997) are gradually compensated by more rapid flow-induced thinning of the layers. In a similar way, because NGRIP has a present-day annual accumulation rate of $19 \mathrm{~cm}$ (ice equivalent) (NGRIP members, 2004) while GRIP receives $23 \mathrm{~cm}$ (ice equivalent) per year (Johnsen et al., 1992), the GRIP-NGRIP depth difference (Fig. 2, green) is positive in the top of the core and increases until match point 30 (about $1820 \mathrm{~m}$ NGRIP depth, $1979 \mathrm{~m}$ GRIP depth), where the more rapid layer thinning at GRIP results in thinner annual layers in the GRIP core than in NGRIP, corresponding to negative slope of the depth difference curve. The same effect is seen for the GISP2-NGRIP depth difference (Fig. 2a, orange). Superimposed on this general trend an unexpected feature appears between match points 9 and 10 (grey shaded intervals). This $1.8 \mathrm{ky}$ long interval is characterized by containing no clear match points, but as the match points in both ends are certain it is evident that the GISP2-NGRIP and GISP2-GRIP depth difference curves have bumps across this section. Just above match point 9 and below match point 10, the GISP2 annual layers are $2.5-3 \%$ thinner than those in the NGRIP core (slope between -0.03 and -0.025 ), while the mean slope is 0.060 between match point 9 and 10. The GISP2 annual layers are thus on average about $9 \%$ thicker 
in this period compared to the average value just outside this time period. When comparing GISP2 and GRIP, the corresponding slopes are -0.057 outside the interval and 0.009 inside, reflecting on average about $7 \%$ thicker annual layers in the GISP2 ice core. The NGRIP-GRIP depth difference curve shows a small anomaly just below the GISP2 annual layer thickness anomaly (match points 10 - 13), but the magnitude of this anomaly is only $20 \mathrm{~cm}$.

It should be noted that the magnitude and location of the bumps in the GISP2NGRIP and GISP2-GRIP depth difference curves are supported by an independent matching of the GRIP and GISP2 cores (pers. comm. R. Rohde, 2006) using data from an optical dust logging device (Bay et al., 2001).

\section{Discussion}

The match points in Table 2 and the match points of Rasmussen et al. (2006), covering in total the period from GI-5 to the onset of the Holocene, comprise a common stratigraphy of the three cores. Using this stratigraphy, the NGRIP-based GICC05 time scale can be applied to the GRIP and GISP2 cores, making the records of the three cores available on a common time scale. NGRIP depths corresponding

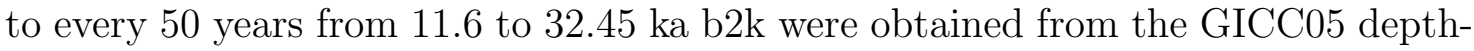
age relation (Rasmussen et al., 2006; Andersen et al., accepted). These depths were converted to GRIP and GISP2 depths using linear interpolation between the match point depths. In longer sections without match points the interpolation introduces a significant uncertainty in the calculated GRIP and GISP2 depths. We estimate that the maximum possible depth offset is 0.5 meter, corresponding to a shift of about 20 years, except for the interval bounded by match points 24 and 28 as described in section 4. In Fig. 3 we present 50 year average values of the $\delta^{18} \mathrm{O}$ and $\left[\mathrm{Ca}^{2+}\right]$ records from the NGRIP, GRIP and GISP2 cores on the GICC05 time scale, based on the data sets listed in Table 1 . Note the reversed logarithmic scale of the $\left[\mathrm{Ca}^{2+}\right]$ curve. The records are shown over the 11.6 to $32.45 \mathrm{ka} b 2 \mathrm{k}$ period. The location of the NGRIP-GRIP (red dots) and NGRIP-GISP2 match points (green dots) used for the synchronization are shown in the top. The synchronization of the NGRIP, GRIP, and GISP2 records makes it possible to assess similarities and differences between these key records of the late glacial climate. The $\delta^{18} \mathrm{O}$ and $\left[\mathrm{Ca}^{2+}\right]$ profiles of the three cores are seen to be very well aligned at all stadial-interstadial transitions. In contrast to the synchronicity of the onsets and terminations of interstadials, significant differences between the three $\delta^{18} \mathrm{O}$ profiles are found within all climatic stages, probably reflecting variations in moisture transport to the Greenland ice cap. The most pronounced differences between the three ice core records will be described in the following sections. 


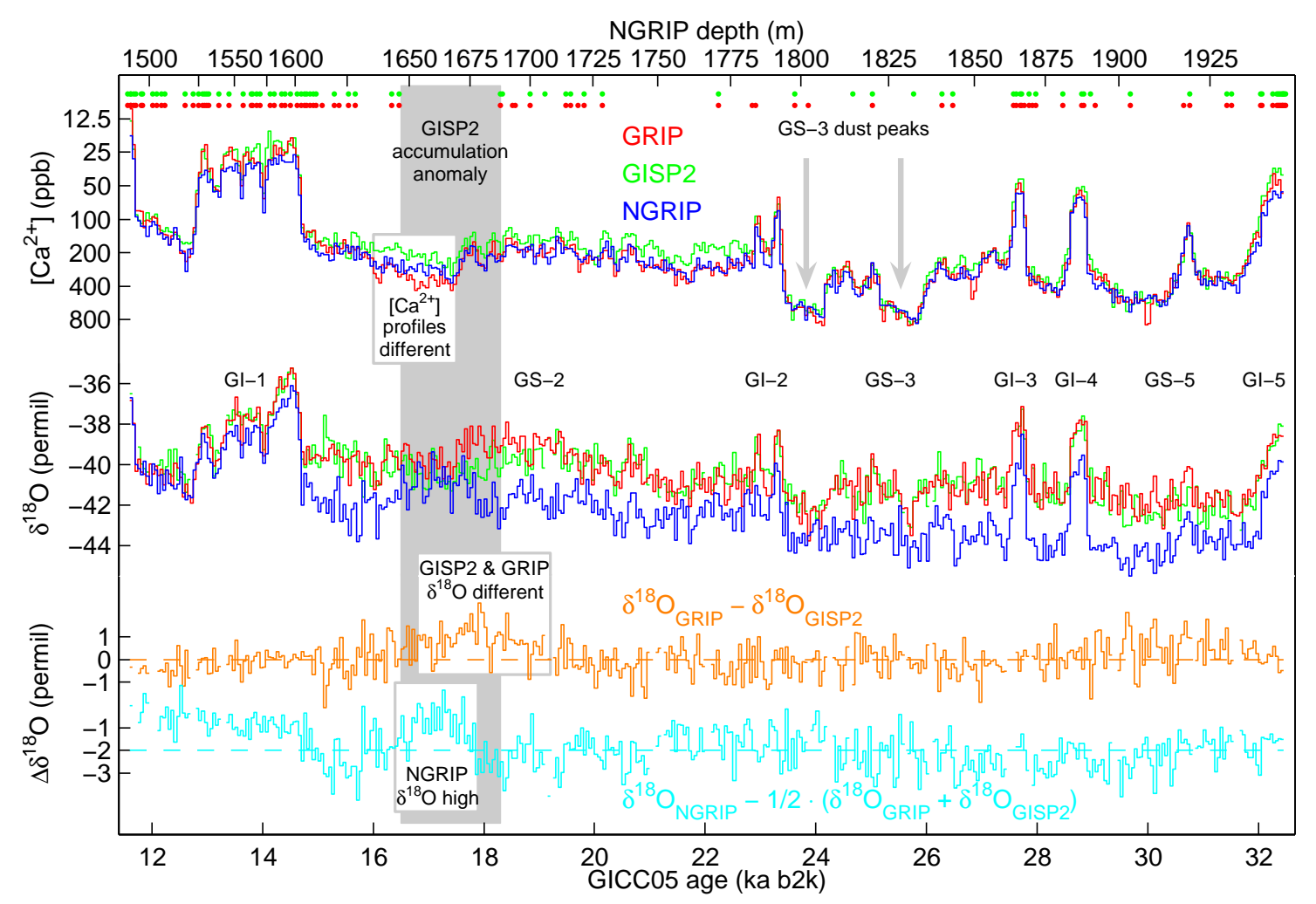

Fig. 3. 50 year average values of $\delta^{18} \mathrm{O}$ and $\left[\mathrm{Ca}^{2+}\right]$ (see Table 1 for data sources) on the GICC05 time scale (GRIP (red), GISP2 (green), NGRIP (blue)). The dots in the top show the position of the match points used to synchronize the NGRIP ice core with the GRIP (red dots) and GISP2 (green dots) cores. In the bottom of the plot, the differences between the isotope curves are illustrated: the orange curve shows the difference between the $\delta^{18} \mathrm{O}$ values in GRIP and GISP2, while the cyan curve shows the $\delta^{18} \mathrm{O}$ offset between the NGRIP profile and the mean of the GRIP and GISP2 profiles. The shaded interval marks the GISP2 accumulation anomaly, and the three boxes indicate the position of areas of anomalous $\delta^{18} \mathrm{O}$ values and $\left[\mathrm{Ca}^{2+}\right]$ values (see section 5 for further discussion of these anomalies). Greenland Stadials (GS) and Greenland Interstadials (GI) are numbered according to the convention of Björck et al. (1998) and Walker et al. (1999). A similar graph with 20 year resolution is available as supplementary information.

\subsection{GISP2 accumulation anomaly}

As described in section 4, the depth difference curves derived from the match points of the synchronization show that the mean GISP2 annual layer thicknesses are unusually large compared to the annual layer thicknesses in the GRIP and NGRIP cores in the $16.5-18.3 \mathrm{ka} \mathrm{b} 2 \mathrm{k}$ interval. This is emphasized in Fig. 4, showing the mean annual layer thicknesses $\lambda$ of the three cores across GS-2. From the figure it is apparent that the GISP2 $\lambda$ curve deviates markedly from the NGRIP and

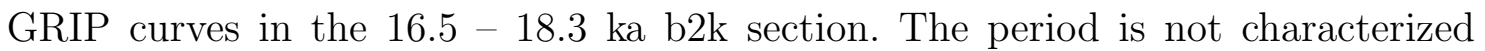
by stadial-interstadial transitions or other abrupt climatic shifts, and we are not aware of any flow phenomena that can produce such a short and abrupt annual 


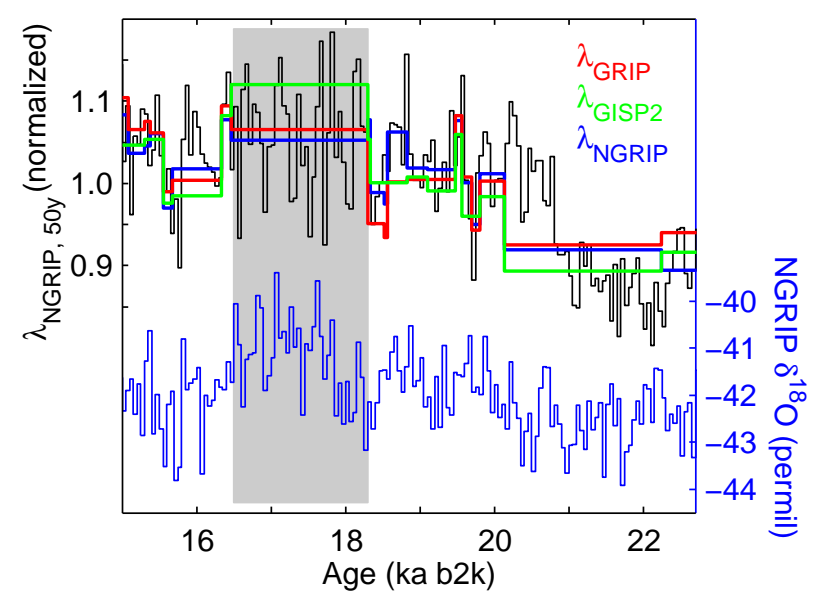

Fig. 4. Annual layer thicknesses $\lambda$ across GS-2 for the three synchronized cores (top curves), normalized to unit mean for each core. Using the match points of Table 2, the mean $\lambda$ between each set of adjacent match points is calculated for the NGRIP, GRIP, and GISP2 cores (thick coloured lines). The period of elevated GISP2 annual layer thicknesses (marked by the grey shade) stands out clearly. The black curve shows 50 year average $\lambda$ from annual layer counting in the NGRIP core (Andersen et al., accepted). Comparing the 50 year $\lambda$ curve with the $\delta^{18} \mathrm{O}$ curve below illustrates that there is no strong coupling of $\lambda$ and $\delta^{18} \mathrm{O}$ in the GS-2 period.

layer thickness anomaly, and we thus consider it most likely that the annual layer thickness anomaly is caused by GISP2 receiving more precipitation than usual. The accumulation increase is $7-9 \%$ on average over the entire period, but the exact timing and duration of the anomaly cannot be determined due to lack of match points within the $16.5-18.3 \mathrm{ka} \mathrm{b} 2 \mathrm{k}$ interval. If the duration of the period with elevated accumulation rates is shorter, the amplitude of the anomaly must have been correspondingly higher. The cause of the increased accumulation at GISP2 is not clear, but we suggest that changes in the atmospheric circulation could lead to larger spatial gradients across Greenland, possibly because the NGRIP/GRIP and GISP2 drill sites are influenced by air masses of different origin. The location of the GISP2 accumulation anomaly is marked in Fig. 3 with a grey shaded band.

\subsection{The $\delta^{18} \mathrm{O}$ profiles}

In general the GRIP and GISP2 $\delta^{18} \mathrm{O}$ profiles are very similar and agree on the shape and timing of the abrupt stadial-interstadial transitions. In contrast to this, the curves have significant differences on the centennial scale. The difference between the GRIP and GISP2 isotope profiles is presented in the lower part of Fig. 3 (orange curve, dashed line marks the zero level), and shows that the GRIP and GISP2 $\delta^{18} \mathrm{O}$ values in each 50 year interval typically differ by $1-2$ permil, but that there are no persistent differences apart from in the 16.8 - $19.2 \mathrm{ka} \mathrm{b} 2 \mathrm{k}$ interval, in which the GRIP $\delta^{18} \mathrm{O}$ values are $1-2$ permil higher than the GISP2 values. This period is 
marked by a box in Fig. 3 .

The NGRIP $\delta^{18} \mathrm{O}$ values are in general about 2 permil lower than the GRIP and GISP2 values in the glacial as also reported by NGRIP members (2004). The difference is seen most clearly from the cyan curve in Fig. 3, where the offset of the NGRIP $\delta^{18} \mathrm{O}$ profile relative to the average GRIP-GISP2 values is shown (dashed line marks the -2 permil level). In contrast to this general observation, the NGRIP $\delta^{18} \mathrm{O}$ values rise to the same level as the GRIP and GISP2 $\delta^{18} \mathrm{O}$ values in the period $16.4-17.9$ ka b2k (marked by a box in Fig. 3). After this excursion, NGRIP $\delta^{18} \mathrm{O}$ values return to a level $2-3$ permil below GRIP and GISP2 values until the onset of the warm GI-1 period, in which the offset disappears.

Using the accumulation rate- $\delta^{18} \mathrm{O}$ relationship of the ss09sea age model, the NGRIP $\delta^{18} \mathrm{O}$ anomaly implies an increase in modelled annual layer thicknesses of about $20 \%$. From Fig. 4 it is clear that no significant changes in mean annual layer thicknesses occur contemporaneous with the $\delta^{18} \mathrm{O}$ maximum, and it is therefore concluded that the accumulation rates and $\delta^{18} \mathrm{O}$ are decoupled in GS-2 and in the $16.5-18.3 \mathrm{ka}$ b2k period in particular (Andersen et al., accepted; Svensson et al., accepted).

\subsection{The $\left[\mathrm{Ca}^{2+}\right]$ profiles}

The $\mathrm{Ca}^{2+}$ concentration in the different cores clearly anti-correlates with the $\delta^{18} \mathrm{O}$ profiles (note the reversed logarithmical scale) as has generally been noted for Greenland ice cores (e.g. Fuhrer et al., 1999). The $\left[\mathrm{Ca}^{2+}\right]$ concentration in the GISP2 cores tends to be somewhat lower than in the other cores, most notably during the cold GS-2 period. The largest differences between the three $\left[\mathrm{Ca}^{2+}\right]$ profiles is seen in the $16-17.5 \mathrm{ka} \mathrm{b} 2 \mathrm{k}$ interval, in which the $\left[\mathrm{Ca}^{2+}\right]$ values also are slightly increased relative to the rest of GS-2. This period is marked with a box in Fig. 3.

A special feature of the $\left[\mathrm{Ca}^{2+}\right]$ profiles is the two very distinct events in GS-3 first reported by Hammer et al. (1985), in which the dust levels increase by a factor of 3 in the NGRIP core (Ruth et al., 2003), and the $\left[\mathrm{Ca}^{2+}\right]$ content in all three cores increases from about $200-300$ to $700-800 \mathrm{ppb}$. The younger of the two peaks is contemporaneous with a $\delta^{18} \mathrm{O}$ minimum in the GRIP and GISP2 curves, while the older dust peak is not reflected in the $\delta^{18} \mathrm{O}$ profiles. When the onsets and terminations are defined as the midpoints of the slopes in 20 year averaged $\left[\mathrm{Ca}^{2+}\right]$ data, the events date to $(23,380 \pm 20)-(24,150 \pm 10) \mathrm{b} 2 \mathrm{k}$ and $(25,140 \pm 20)-$ $(25,980 \pm 60)$ b2k in GICC05, respectively, where the quoted uncertainty arises from the fact that the onsets and terminations are not instantaneous and well-defined. The absolute GICC05 maximum counting error at this depth is about 700 years (see Table 1 and Andersen et al. (accepted)), but from the difference in maximum counting error the uncertainty in the number of years across each of the events is less than 50 years. Adding up the uncertainties is not straightforward, but the event 
durations are approximately 770 years for the younger event and 840 years for the older with an estimated precision of a hundred years or better. From Fig. 3 it is also apparent that the termination of the younger dust peak coincides with the onset of GI-2.

Generally, the three $\left[\mathrm{Ca}^{2+}\right]$ profiles show a consistent picture and display strong and synchronous climatic variations. Only short sporadic $\left[\mathrm{Ca}^{2+}\right]$ peaks connected to volcanic events were occasionally used as match points, and the close agreement between the profiles is therefore not implicit from the matching. The synchronicity of the profiles shows that if a volcanic match cannot be performed, $\left[\mathrm{Ca}^{2+}\right]$ is a better parameter for matching than $\delta^{18} \mathrm{O}$, as the $\left[\mathrm{Ca}^{2+}\right]$ profiles of the three cores in general agree better than the $\delta^{18} \mathrm{O}$ profiles on the timing of transitions (see also the 20 year resolved version of Fig. 3, provided as supplementary information). As pointed out by Mulvaney et al. (2000), the greater similarity of the $\left[\mathrm{Ca}^{2+}\right]$ records than of the $\delta^{18} \mathrm{O}$ records can be explained by the large distance to the dust sources, that are known to be located mainly in Asia (Biscaye et al., 1997). According to this argument, the dust content in Greenland ice cores is modulated primarily by the source efficiency and transport paths, leading to roughly similar dust flux to the entire Central Greenland area, while the $\delta^{18} \mathrm{O}$ profiles are less similar due to differences in source areas between the cores and the influence of local temperature and circulation effects. Especially in the period from GI-2 through GI-5, the concentrations of $\mathrm{Ca}^{2+}$ in the three cores are remarkably similar. Although the (present day) accumulation rate differences between the three cores are more than $20 \%$, the $\mathrm{Ca}^{2+}$ concentrations are within $8 \%$ of each other (mean concentration $385 \mathrm{ppb}$ for NGRIP, $381 \mathrm{ppb}$ for GRIP, and $357 \mathrm{ppb}$ for GISP2). This indicates that during GS2 through GS-5, the $\mathrm{Ca}^{2+}$ concentration in Greenland snow is only slightly affected by the amount of precipitation.

\section{Conclusion}

We have presented a synchronization of the NGRIP, GRIP, and GISP2 ice cores from the onset of GI-1 to GI-5 (14.9 - 32.45 ka b2k). Together with the match points of Rasmussen et al. (2006), the synchronization has made it possible to extend the GICC05 time scale to the GRIP and GISP2 cores from the onset of the Holocene to GI-5. The matching reveals that the accumulation rate at the GISP2 drill site was elevated by $7-9 \%$ on average relative to GRIP and NGRIP over the $16.5-$ $18.3 \mathrm{ka}$ b2k period. Around this time, anomalous events in the NGRIP, GRIP, and GISP2 $\delta^{18} \mathrm{O}$ and $\left[\mathrm{Ca}^{2+}\right]$ profiles are observed. Some of the same features are seen for the period $21-24 \mathrm{ka} \mathrm{b2k}$, including the scarcity of good match points, but with smaller magnitude and without the strong anomaly in annual layer thickness. Over the remaining period, the synchronized profiles of $\delta^{18} \mathrm{O}$ and $\left[\mathrm{Ca}^{2+}\right]$ show very good agreement, especially across the stadial-interstadial transitions and during the two characteristic dust events of GS-3. 
The fact that the anomalies are all located within the same 3 ky long period (compare the timing of the anomalies in Fig. 3) indicates that their causes may very well be connected. However, from the $\delta^{18} \mathrm{O}$ difference curves of Fig. 3 it is clear that the duration of the GRIP-GISP2 offset is not contemporaneous with the interval of high NGRIP $\delta^{18} \mathrm{O}$ values. This offset in timing, and the stable $\delta^{18} \mathrm{O}$ values of the GISP2 core, make it unlikely that the anomalies are caused by a movement of the polar front or other large-scale changes in atmospheric circulation (as suggested by Masson-Delmotte et al., 2005a, for stadial-interstadial transitions), as such changes would be observed all over Greenland, although possibly with different amplitudes at the different sites. Instead, we suggest that the anomalous conditions are related to changes in the source areas of the precipitation received at the three sites, probably due to circulation changes or changes in sea ice extent. More investigations using combined high-resolution $\delta D$ and $\delta^{18} \mathrm{O}$ data are needed to identify possible changes in source and drill site temperatures during this time interval. Indeed, such changes have been derived from $\delta^{18} \mathrm{O}$ and $\delta \mathrm{D}$ profiles from the Holocene (Masson-Delmotte et al., 2005b), which is in line with the observed decoupling of $\delta^{18} \mathrm{O}$ and accumulation rates in this period (Andersen et al., accepted; Svensson et al., accepted).

The synchronization provides improved basis for interpreting the climatic information from the three cores in the late glacial period, and the common time scale makes it possible to assess differences in the climatic information contained in these key records of the glacial climate. We are confident that the advent of common chronological frameworks in ice core studies will improve the understanding of the climate system and add to our knowledge on the underlying dynamics.

\section{Supplementary information}

A figure similar to Fig. 3, but with 20 year resolution, is available as supplementary information.

\section{Data access}

An electronic version of Table 2 and the corresponding match points in the $8.2-14.8$ ka b2k period from Rasmussen et al. (2006) are available from http://www.icecores.dk together with 20 and 50 year mean values of $\delta^{18} \mathrm{O}$ and $\left[\mathrm{Ca}^{2+}\right]$ from both the NGRIP, GRIP, and GISP2 ice cores on the GICC05 time scale. The customized Matlab application for ice core synchronization ("Matchmaker") can be obtained from SOR upon request. 


\section{Acknowledgements}

This work is a contribution of the Copenhagen Ice Core Dating Initiative which is supported by a grant from the Carlsberg Foundation. IKS is funded by the Danish Research Agency through the ESF RESOLuTION programme.

\section{Tables}

\begin{tabular}{|c|c|c|c|c|c|}
\hline Core & Data series & Method & Data Coverage & Depth res. $(\mathrm{cm})$ & Reference \\
\hline \multirow[t]{5}{*}{ GRIP } & ECM & & Continuous & 0.1 & Taylor et al. (1993); Moore et al. (1994); Wolff et al. (1997) \\
\hline & DEP & & Continuous pointwise & 2 & Taylor et al. (1993); Moore et al. (1994); Wolff et al. (1997) \\
\hline & {$\left[\mathrm{SO}_{4}^{2-}\right]$} & IC & Discontinuous, discrete & $2.5-5$ & \\
\hline & {$\left[\mathrm{NH}_{4}^{+}\right],\left[\mathrm{Ca}^{2+}\right]$} & CFA & Continuous $^{\dagger}$ & 0.2 & Fuhrer et al. $(1993,1996)$ \\
\hline & $\delta^{18} \mathrm{O}$ & & Continuous, discrete & $6.9-13.8$ & Johnsen et al. (1997) \\
\hline \multirow[t]{4}{*}{ NGRIP } & ECM & & Continuous & 0.1 & Dahl-Jensen et al. (2002) \\
\hline & DEP & & Continuous pointwise & 0.5 & Dahl-Jensen et al. (2002) \\
\hline & {$\left[\mathrm{SO}_{4}^{2-}\right],\left[\mathrm{NH}_{4}^{+}\right],\left[\mathrm{Ca}^{2+}\right]$} & CFA & Continuous & 0.1 & Bigler (2004) \\
\hline & $\delta^{18} \mathrm{O}$ & & Continuous, discrete & 5 & NGRIP members (2004) \\
\hline \multirow[t]{3}{*}{ GISP2 } & $\mathrm{ECM}$ & & Continuous & 0.1 & Taylor et al. $(1993,1997)$ \\
\hline & {$\left[\mathrm{SO}_{4}^{2-}\right],\left[\mathrm{NH}_{4}^{+}\right],\left[\mathrm{Ca}^{2+}\right]$} & IC & Continuous, discrete & 20 & Mayewski et al. (1997); Taylor et al. (1996) \\
\hline & $\delta^{18} \mathrm{O}$ & & Continuous, discrete & 20 & Stuiver and Grootes (2000); Grootes and Stuiver (1997) \\
\hline
\end{tabular}

† $\left[\mathrm{NH}_{4}^{+}\right]$data not available in the $2065-2281 \mathrm{~m}$ interval.

Table 1

Data series used for the matching (ECM, DEP, $\left.\left[\mathrm{SO}_{4}^{2-}\right],\left[\mathrm{NH}_{4}^{+}\right]\right)$and data presented in Fig. $2\left(\delta^{18} \mathrm{O},\left[\mathrm{Ca}^{2+}\right]\right)$. 


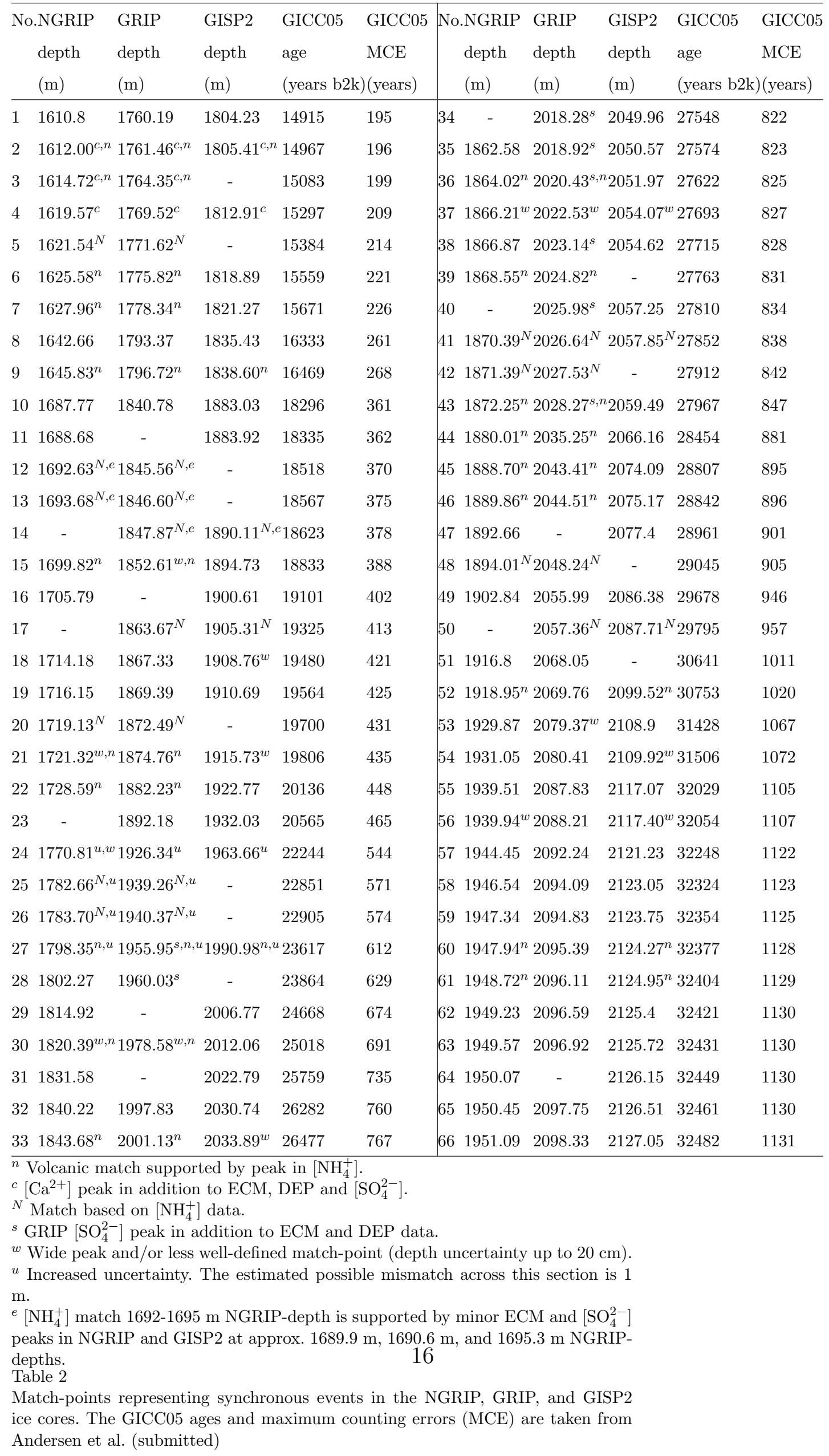




\section{References}

Alley, R., Meese, D., Shuman, C., Gow, A., Taylor, K., Grootes, P., White, J., Ram, M., Waddington, E., Mayewski, P., Zielinski, G., 1993. Abrupt increase in Greenland snow accumulation at the end of the Younger Dryas event. Nature 362 (6420), 527-529.

Alley, R. B., Shuman, C. A., Meese, D. A., Gow, A. J., Taylor, K. C., Cuffey, K. M., Fitzpatrick, J. J., Grootes, P. M., Zielinski, G. A., Ram, M., Spinelli, G., Elder, B., 1997. Visual-stratigraphic dating of the GISP2 ice core: Basic, reproducibility, and application. Journal of Geophysical Research 102 (C12), 26367-26381.

Andersen, K. K., Svensson, A., Johnsen, S., Rasmussen, S. O., Bigler, M., Röthlisberger, R., Ruth, U., Siggaard-Andersen, M.-L., Steffensen, J. P., DahlJensen, D., Vinther, B. M., Clausen, H. B., accepted. The Greenland Ice Core Chronology 2005, 15-42 kyr. Part 1: Constructing the time scale, Quaternary Science Reviews.

Bay, R. C., Bramall, N. E., Price, P. B., Clow, G. D., Hawley, R. L., Udisti, R., Castellano, E., 2006. Globally synchronous ice core volcanic tracers and abrupt cooling during the last glacial period. Journal of Geophysical Research 111, D11108.

Bay, R. C., Price, P. B., Clow, G. D., Gow, A. J., 2001. Climate logging with a new rapid optical technique at Siple Dome. Geophysical Research Letters 28 (24), 4635-4638.

Bender, M., Sowers, T., Dickson, M.-L., Orchardo, J., Grootes, P., Mayewski, P., Meese, D., 1994. Climate correlations between Greenland and Antarctica during the last 100,000 years. Nature 372 (6507), 663-666.

Bigler, M., 2004. Hochauflösende Spurenstoffmessungen an polaren Eisbohrkernen: Glaziochemische und klimatische Prozessstudien, Ph.D. dissertation, University of Bern, Switzerland.

Bigler, M., Wagenbach, D., Fischer, H., Kipfstuhl, J., Miller, H., Sommer, S., Stauffer, B., 2002. Sulphate record from a northeast Greenland ice core over the last 1200 years based on continuous flow analysis. Annals of Glaciology 35, 250-256.

Biscaye, P. E., Grousset, F. E., Revel, M., Van der Gaast, S., Zielinski, G. A., Vaars, A., Kukla, G., 1997. Asian provenance of glacial dust (stage 2) in the Greenland Ice Sheet Project 2 ice core, Summit, Greenland. Journal of Geophysical Research 102 (C12), 26765-26781.

Björck, S., Walker, M. J. C., Cwynar, L. C., Johnsen, S., Knudsen, K.-L., Lowe, J. J., Wohlfarth, B., INTIMATE Members, 1998. An event stratigraphy for the Last Termination in the North Atlantic region based on the Greenland ice-core record: a proposal by the INTIMATE group. Journal of Quaternary Science 13 (4), $283-292$.

Blunier, T., Brook, E. J., 2001. Timing of millennial-scale climate change in Antarctica and Greenland during the last glacial period. Science 291, 109-112.

Blunier, T., Schwander, J., 2000. Gas enclosure in ice: Age difference and fractionation. In: Hondoh, T. (Ed.), Physics of Ice Core Records. Hokkaido University Press, Sapporo, pp. 307-326. 
Clausen, H., Hammer, C., Hvidberg, C., Dahl-Jensen, D., Steffensen, J., Kipfstuhl, J., Legrand, M., 1997. A comparison of the volcanic records over the past 4000 years from the Greenland Ice Core Project and DYE-3 Greenland ice cores. Journal of Geophysical Research 102 (C12), 26707-26723.

Dahl-Jensen, D., Gundestrup, N. S., Miller, H., Watanabe, O., Johnsen, S. J., Steffensen, J. P., Clausen, H. B., Svensson, A., Larsen, L. B., 2002. The NorthGRIP deep drilling programme. Annals of Glaciology 35, 1-4.

Dansgaard, W., Johnsen, S., Clausen, H., Dahl-Jensen, D., Gundestrup, N., Hammer, C., Hvidberg, C., Steffensen, J., Sveinbjörnsdottir, A., Jouzel, J., Bond, G., 1993. Evidence for general instability of past climate from a 250-kyr ice-core record. Nature 364 (6434), 218-220.

Fisher, D. A., Reeh, N., Clausen, H. B., 1985. Stratigraphic noise in time series derived from ice cores. Annals of Glaciology 7, 76-83.

Fuhrer, K., Neftel, A., Anklin, M., Maggi, V., 1993. Continuous measurements of hydrogen peroxide, formaldehyde, calcium and ammonium concentrations along the new GRIP ice core from Summit, Central Greenland. Atmospheric Environment 27A (12), 1873-1880.

Fuhrer, K., Neftel, A., Anklin, M., Staffelbach, T., Legrand, M., 1996. Highresolution ammonium ice core record covering a complete glacial-interglacial cycle. Journal of Geophysical Research 101 (D2), 4147-4164.

Fuhrer, K., Wolff, E. W., Johnsen, S. J., 1999. Timescales for dust variability in the Greenland Ice Core Project (GRIP) ice core in the last 100,000 years. Journal of Geophysical Research 104 (D24), 31043-31052.

Grönvold, K., Óskarsson, N., Johnsen, S. J., Clausen, H. B., Hammer, C. U., Bond, G., Bard, E., 1995. Ash layers from Iceland in the Greenland GRIP ice core correlated with oceanic and land sediments. Earth and Planetary Science Letters $135,149-155$.

Grootes, P. M., Stuiver, M., 1997. Oxygen 18/16 variability in Greenland snow and ice with $10^{-3}$ to $10^{5}$-year time resolution. Journal of Geophysical Research 102, 26455-26470.

Hammer, C., Clausen, H., Dansgaard, W., 1980. Greenland ice sheet evidence of post-glacial volcanism and its climatic impact. Nature 288, 230-235.

Hammer, C., Clausen, H., Dansgaard, W., Neftel, A., Kristinsdottir, P., Johnson, E., 1985. Continuous impurity analysis along the Dye-3 deep core. In: Langway, C.C., J., Oeschger, H., Dansgaard, W. (Eds.), Greenland Ice Core: Geophysics, Geochemistry, and the Environment. Geophys. Monogr. Ser., vol. 33. American Geophysical Union (AGU), Washington, D.C., pp. 90-94.

Hammer, C., Clausen, H., Langway, C.C., J., 1997. 50,000 years of recorded global volcanism. Climatic Change 35 (1), 1-15.

Hammer, C. U., 1980. Acidity of polar ice cores in relation to absolute dating, past volcanism, and radio-echoes. Journal of Glaciology 25 (93), 359-372.

Johnsen, S., Dahl-Jensen, D., Dansgaard, W., Gundestrup, N., 1995. Greenland palaeotemperatures derived from GRIP bore hole temperature and ice core isotope profiles. Tellus 47B, 624-629.

Johnsen, S. J., Clausen, H. B., Dansgaard, W., Fuhrer, K., Gundestrup, N., Ham- 
mer, C. U., Iversen, P., Jouzel, J., Stauffer, B., Steffensen, J. P., 1992. Irregular glacial interstadials recorded in a new Greenland ice core. Nature 359, 311-313.

Johnsen, S. J., Clausen, H. B., Dansgaard, W., Gundestrup, N. S., Hammer, C. U., Andersen, U., Andersen, K. K., Hvidberg, C. S., Dahl-Jensen, D., Steffensen, J. P., Shoji, H., Sveinbjörnsdóttir, Á. E., White, J., Jouzel, J., Fisher, D., 1997. The $\delta^{18} \mathrm{O}$ record along the Greenland Ice Core Project deep ice core and the problem of possible Eemian climatic instability. Journal of Geophysical Research 102 (C12), 26397-26410.

Johnsen, S. J., Dahl-Jensen, D., Gundestrup, N., Steffensen, J. P., Clausen, H. B., Miller, H., Masson-Delmotte, V., Sveinbjörnsdottir, A. E., White, J., 2001. Oxygen isotope and palaeotemperature records from six Greenland ice-core stations: Camp Century, Dye-3, GRIP, GISP2, Renland and NorthGRIP. Journal of Quaternary Science 16, 299-307.

Langway, C. C., Clausen, H. B., Hammer, C. U., 1988. An inter-hemispheric volcanic time-marker in ice cores from Greenland and Antarctica. Annals of Glaciology $10,102-108$.

Masson-Delmotte, V., Jouzel, J., Landais, A., Stievenard, M., Johnsen, S. J., White, J. W. C., Werner, M., Sveinbjornsdottir, A., Fuhrer, K., 2005a. GRIP deuterium excess reveals rapid and orbital-scale changes in Greenland moisture origin. Science 209, 118-121.

Masson-Delmotte, V., Landais, A., Stievenard, M., Cattani, O., Falourd, S., Jouzel, J., Johnsen, S. J., Dahl-Jensen, D., Sveinsbjornsdottir, A., White, J. W. C., Popp, T., Fischer, H., 2005b. Holocene climatic changes in Greenland: Different deuterium excess signals at Greenland Ice Core Project (GRIP) and NorthGRIP. Journal of Geophysical Research 110, D14102.

Mayewski, P., Meeker, L., Twickler, M., Whitlow, S., Yang, Q., Lyons, W., Prentice, M., 1997. Major features and forcing of high-latitude northern hemisphere atmospheric circulation using a 110,000-year-long glaciochemical series. Journal of Geophysical Research 102, 26345-26366.

Meese, D. A., Gow, A. J., Alley, R. B., Zielinski, G. A., Grootes, P. M., Ram, M., Taylor, K. C., Mayewski, P. A., Bolzan, J. F., 1997. The Greenland Ice Sheet Project 2 depth-age scale: Methods and results. Journal of Geophysical Research 102 (C12), 26411-26423.

Moore, J. C., Mulvaney, R., Paren, J., 1989. Dielectric stratigraphy of ice: A new technique for determining total ionic concentrations in polar ice cores. Geophysical Research Letters 16, 1177-1180.

Moore, J. C., Wolff, E. W., Clausen, H. B., Hammer, C. U., Legrand, M. R., Fuhrer, K., 1994. Electrical response of the Summit-Greenland ice core to ammonium, sulphuric acid, and hydrochloric acid. Geophysical Research Letters 21 (7), 565568.

Mortensen, A., Bigler, M., Grönvold, K., Steffensen, J., Johnsen, S., 2005. Volcanic ash layers from the Last Glacial Termination in the NGRIP ice core. Journal of Quaternary Science 20 (3), 209-219.

Mulvaney, R., Röthlisberger, R., Wolff, E. W., Sommer, S., Schwander, J., Hutterli, M. A., Jouzel, J., 2000. The transition from the last glacial period in inland and 
near-coastal Antarctica. Geophysical Research Letters 27 (17), 2673-2676.

NGRIP members, 2004. High-resolution record of Northern Hemisphere climate extending into the last interglacial period. Nature 431, 147-151.

Palais, J., Taylor, K., Mayewski, P., Grootes, P., 1991. Volcanic ash from the 1362 A.D. Oræfajökull eruption (Iceland) in the Greenland ice sheet. Geophysical Research Letters 18 (7), 1241-1244.

Palmer, A. S., van Ommen, T. D., Curran, M. A. J., Morgan, V., Souney, J. M., Mayewski, P. A., 2001. High-precision dating of volcanic events (A.D. 1301 - 1995) using ice cores from Law Dome, Antarctica. Journal of Geophysical Research 106 (D22), 28,089-28,095.

Rasmussen, S. O., Andersen, K. K., Svensson, A. M., Steffensen, J. P., Vinther, B., Clausen, H. B., Siggaard-Andersen, M.-L., Johnsen, S. J., Larsen, L. B., DahlJensen, D., Bigler, M., Röthlisberger, R., Fischer, H., Goto-Azuma, K., Hansson, M., Ruth, U., 2006. A new Greenland ice core chronology for the last glacial termination. Journal of Geophysical Research 111, D06102.

Rasmussen, S. O., Vinther, B. M., Clausen, H. B., Andersen, K. K., accepted. Early Holocene climate oscillations recorded in three Greenland ice cores, Quaternary Science Reviews.

Röthlisberger, R., Bigler, M., Hutterli, M., Sommer, S., Stauffer, B., Junghans, H., Wagenbach, D., 2000. Technique for continuous high-resolution analysis of trace substances in firn and ice cores. Environmental Science and Technology 34 (2), $338-342$.

Ruth, U., Wagenbach, D., Steffensen, J., Bigler, M., 2003. Continuous record of microparticle concentration and size distribution in the central Greenland NGRIP ice core during the last glacial period. Journal of Geophysical Research. 108, 4098.

Southon, J., 2004. A radiocarbon perspective on Greenland ice-core chronologies: Can we use ice cores for ${ }^{14} \mathrm{C}$ calibration? Radiocarbon 46 (3), 1239-1260.

Stuiver, M., Grootes, P. M., 2000. GISP2 Oxygen isotope ratios. Quaternary Research 53, 277-284.

Svensson, A., Andersen, K. K., Bigler, M., Clausen, H. B., Dahl-Jensen, D., Davies, S. M., Johnsen, S. J., Muscheler, R., Rasmussen, S. O., Röthlisberger, R., Steffensen, J. P., Vinther, B. M., accepted. The Greenland Ice Core Chronology 2005, 15-42 kyr. Part 2: Comparison to other records, Quaternary Science Reviews.

Taylor, K., Alley, R., Lamorey, G., Mayewski, P., 1997. Electrical measurements on the Greenland Ice Sheet Project 2 core. Journal of Geophysical Research 102, 26511-26517.

Taylor, K., Hammer, C., Alley, R., Clausen, H., Dahl-Jensen, D., Gow, A., Gundestrup, N., Kipfstuhl, J., Moore, J., Waddington, E., 1993. Electrical conductivity measurements from the GISP2 and GRIP Greenland ice cores. Nature 366, 549552.

Taylor, K., Mayewski, P., Twickler, M., Whitlow, S., 1996. Biomass burning recorded in the GISP2 ice core: A record from eastern Canada? The Holocene $6(1), 1-6$.

Udisti, R., Becagli, S., Castellano, E., Delmonte, B., Jouzel, J., Petit, J. R., Schwander, J., Stenni, B., Wolff, E. W., 2004. Stratigraphic correlations between the 
European Project for Ice Coring in Antarctica (EPICA) Dome C and Vostok ice cores showing the relative variations of snow accumulation over the past $45 \mathrm{kyr}$. Journal of Geophysical Research 109, D08101.

Vinther, B. M., Clausen, H. B., Johnsen, S. J., Rasmussen, S. O., Andersen, K. K., Buchardt, S. L., Dahl-Jensen, D., Seierstad, I. K., Siggaard-Andersen, M.-L., Steffensen, J. P., Svensson, A. M., Olsen, J., Heinemeier, J., 2006. A synchronized dating of three Greenland ice cores throughout the Holocene. Journal of Geophysical Research 111, D13102.

Walker, M. J. C., Björck, S., Lowe, J. J., Cwynar, L. C., Johnsen, S., Knudsen, K.-L., Wohlfarth, B., 1999. Isotopic 'events' in the GRIP ice core: a stratotype for the Late Pleistocene. Quaternary Science Reviews 18 (10-11), 1143-1150.

Wolff, E., Moore, J., Clausen, H., Hammer, C., 1997. Climatic implications of background acidity and other chemistry derived from electrical studies of the Greenland Ice Core Project ice core. Journal of Geophysical Research 102, 26325-26332.

Wolff, E. W., Basile, I., Petit, J.-R., Schwander, J., 1999. Comparison of Holocene electrical records from Dome C and Vostok. Annals of Glaciology 29, 89-93.

Zielinski, G., 2000. Use of paleo-records in determining variability within the volcanism-climate system. In: Alverson, K., Oldfield, F., Bradley, R. (Eds.), Past Global Changes and their Significance for the Future. Vol. Quaternary Science Reviews, 19(1-5). Pergamon, pp. 417-438.

Zielinski, G., Mayewski, P., Meeker, L., Whitlow, S., Twickler, M., Morrison, M., Meese, D., Gow, A., Alley, R., 1994. Record of volcanism since 7000 B.C. from the GISP2 Greenland ice core and implications for the volcano-climate system. Science 264, 948-952. 